\title{
Juan Pérez de Montalbán, Auto sacramental famoso de las Santísimas Formas de Alcalá, edición de Ignacio Arellano, J. Enrique Duarte y Carlos Mata Induráin, New York, IDEA, 2019, 226 pp. ISBN: 978-1-938795-57-2
}

\section{Iñaki Pérez Ibáñez}

University of Rhode Island

ESTADOS UNIDOS

ignacioperez@uri.edu

[Hipogrifo, (issn: 2328-1308), 8.2, 2020, pp. 899-901]

Recibido: 19-06-2020 / Aceptado: 13-07-2020

DOI: http://dx.doi.org/10.13035/H.2020.08.02.57

En el 2019, coincidiendo con el cuarto centenario de la declaración formal del milagro de las Santas Formas incorruptas de Alcalá, Ignacio Arellano, J. Enrique Duarte y Carlos Mata Induráin colaboraron en la preparación de una cuidada edición crítica del Auto sacramental Famoso de las Santísimas Formas de Alcalá, pieza que escribió Juan Pérez de Montalbán. Además del texto del auto y su correspondiente estudio dramático-literario se incluye en el volumen un estudio histórico, una reproducción facsímil del auto, un apéndice donde se recogen una serie de documentos históricos, otra obra de Pérez de Montalbán titulada Discurso segundo de la misa, en que se declaran sus misterios, voces y ceremonias más particulares y el Entremés famoso de Turrada de Quiñones de Benavente. La inclusión de esta última pieza no es gratuita, sino que quiere «sugerir el conglomerado festivo sacramental característico del Siglo de Oro» (p. 205, n.1).

Los orígenes de la pieza dramática se hallan en la preservación incorrupta a lo largo de los años de las formas consagradas que en 1597 entregó al Padre Juan Juárez un ladrón arrepentido. Durante su confesión este relató cómo junto a un grupo de bandoleros moriscos había asaltado diferentes iglesias y robado las hostias. El Padre Juárez, sospechando que tal vez estas estuviesen envenenadas (corrían rumores de que otros sacerdotes habían muerto tras caer en engaños de este 
tipo) y tras consultar con el superior de su orden, decidió no consumirlas y conservarlas en una caja de plata hasta que las especies se corrompiesen. Sin embargo, esto último nunca llegó a pasar y, de hecho, se conservaron incorruptas hasta que desaparecieron en 1936 durante la Guerra Civil.

Frente a esta obra, nos podemos hacer la misma pregunta que cuando nos enfrentamos a los autos de Lope: el texto dramático que tenemos frente a nosotros ¿es realmente un auto sacramental? La discusión viene de lejos: recordemos que, en el caso de los autos lopianos y dada la relevancia que en ellos tienen los elementos folclóricos y populares, Marcelino Menéndez Pelayo ya consideraba discutible que se les pudiese considerar sacramentales. Más recientemente, en su tesis doctoral Clasificación de los autos sacramentales de Lope de Vega (Universidad de Barcelona, 2011) María Nogués Bruno sugiere una nueva categorización para los autos lopianos y propone referirse a ellos como «autos de circunstancias». En su libro Los autos sacramentales de Lope de Vega. Clasificación e interpretación (Editorial Academia del Hispanismo, 2013) Amparo Izquierdo Domingo se hace eco de dicha denominación. En el caso de la obra de Montalbán, encontramos dos partes claramente diferenciadas. La primera es extraordinariamente cercana a una comedia hagiográfica y nos relata la conversión de un bandolero llamado Andrés Corvino que será quien proteja las Sagradas Formas. La segunda parte tiene un contenido más alegórico y en ella intervienen personajes tales como la Filosofía, la Medicina, la Teología o los Cánones. Aunque los editores reconocen que la presencia de la alegoría es débil y que las formas alegóricas resultan muy rudimentarias, estos se decantan por considerar la obra un auto sacramental ya que la caracterización de los personajes alegóricos se basa en sus atributos iconográficos y, especialmente, porque (siguiendo la distinción calderoniana) el asunto de la obra es claramente eucarístico, aunque el argumento no lo sea.

Por lo que respecta a la datación de la obra, Arellano remite a Garrot Zambrana que ve en los vv. 857-868 del auto una referencia al convulso periodo que se dio en España entre 1629 y 1633. Creemos que vale la pena prestar especial atención a los vv. 862-868:

Y en fin abrasaré por más rigores con mi aliento las flores, con mis voces los ríos

y los sembrados con los ojos míos hasta que un año tan estéril venga que para celebrar aun pan no tenga.

Siguiendo la senda que marcan Garrot Zambrana y Arellano, debemos recordar «la sequía de 1629 [que] causó la práctica desaparición de la cosecha del año 1630, apareciendo en 1631 puntas de mortandad» (Juan E. Gelabert, Castilla convulsa (1631-1652), Marcial Pons, 2001, p. 56). La situación llegó a ser tal que en 1631 se ordenó realizar acopiamientos de trigo. Estos datos no hacen sino apuntalar la hipotética datación sostenida en este volumen. 
Pocos peros se pueden poner a esta cuidada edición excepto alguna que otra repetición entre las diferentes secciones del volumen (por ejemplo, el mismo texto proveniente de Cassani, Glorias del segundo siglo de la Compañía de Jesús..., pp. 664a-665b, aparece citado en el «Estudio histórico» que firma Carlos Mata, pp. 20-21, y 18 páginas más tarde vuelve a recogerse en el «Estudio dramáticoliterario» que firma Arellano, p. 39; otro tanto ocurre con algunas citas de cierta extensión de documentos históricos que aparecen en el estudio preliminar cuando posteriormente se nos presentan dichos documentos en el «Apéndice l: documentos varios»). La anotación resulta pertinente y equilibrada y en ella se recogen suficientes datos y referencias para que resulte de interés para los estudiosos pero sin resultar excesiva para aquellos que se acerquen al texto buscando una comprensión del mismo no tan profunda. Concluiré esta reseña subrayando la extraordinaria pertinencia de la publicación de este auto, que llega en un momento en que la crítica está replanteándose el juicio tradicional que se venía manteniendo sobre el autor. Considerado durante mucho tiempo un escritor de segunda categoría, admirador de Lope, son cada vez más las voces que defienden su calidad como dramaturgo (entre ellas las de Maria Grazia Profeti y el propio Arellano). 